\title{
Characterization of an inducible, membrane-bound iminodiacetate dehydrogenase from Chelatobacter heintzii ATCC 29600
}

\author{
Thomas Uetz ${ }^{1,2}$ \& Thomas Egli* \\ ${ }^{1}$ Federal Institute for Water Resources and Water Pollution Control (EAWAG), \\ and Swiss Federal Institute of Technology, CH-8600 Dübendorf, Switzerland; ${ }^{2}$ Department of Microbiology \\ Biozentrum, University of Basel, CH-4056 Basel, Switzerland (*requests for offprints)
}

Received 10 June 1992; accepted in revised form 8 October 1992

Key words: membrane protein, biodegradation, iminodiacetate, iminodiacetate dehydrogenasi nitrilotriacetate (NTA), ubiquinones

\begin{abstract}
Iminodiacetate (IDA) is a xenobiotic intermediate common to both aerobic and anaerobic metabolism of nitrilotriacetate (NTA). It is formed by either NTA monooxygenase or NTA dehydrogenase. In this paper the detection and characterization of a membrane-bound iminodiacete dehydrogenase (IDA-DH) from Chelatobacter heintzii ATCC 29600 is reported, which oxidizes IDA to glycine and glyoxylate. Out of 15 compounds tested, IDA was the only substrate for the enzyme. Optimum activity of IDA-DH was found at $\mathrm{pH} 8.5$ and $25^{\circ} \mathrm{C}$, respectively, and the $\mathrm{K}_{\mathrm{m}}$ for IDA was found to be $8 \mathrm{mM}$. Activity of the membrane-bound enzyme was inhibited by KCN, antimycine and dibromomethylisopropyl-benzoquinone. When inhibited by KCN IDADH was able to reduce the artificial electron acceptor iodonitrotetrazolium (INT). It was possible to extract IDA-DH from the membranes with $2 \%$ cholate, to reconstitute the enzyme into soybean phospholipid vesicles and to obtain IDA-DH activity (more than $50 \%$ recovery) using ubiquinone $\mathrm{Q}_{1}$ as the intermediate electron carrier and INT as the final electron acceptor. Growth experiments with different substrates revealed that in all NTA-degrading strains tested both NTA monooxygenase and IDA-DH were only expressed when the cells were grown on NTA or IDA. Furthermore, in Cb. heintzii ATCC 29600 growing exponentially on succinate and ammonia, addition of $0.4 \mathrm{~g} \mathrm{l}^{-1}$ NTA led to the induction of the two enzymes within an hour and NTA was utilized simultaneously with succinate. The presence of IDA-DH was confirmed in ten different NTA-degrading strains belonging to three different genera.
\end{abstract}

Abbreviations: cA - component A; cB - component B; DBMIB - dibromomethylisopropyl-benzoquinone; HEPES - hydroxyethylpiperazinethanesulfonic acid; IDA - iminodiacetate, $\mathrm{HN}\left(\mathrm{CH}_{2} \mathrm{COOH}\right)_{2}$; IDA-DH iminodiacetate dehydrogenase; INT - iodonitrotetrazolium chloride; NTA - nitrilotriacetate, $\mathrm{N}\left(\mathrm{CH}_{2} \mathrm{COOH}\right)_{3}$; NTA-MO - nitrilotriacetate monooxygenase; PMS - phenazine methosulphate; SDSPAGE - sodium dodecylsulfate polyacrylamide gel electrophoresis; Suc-DH - succinate dehydrogenase

\section{Introduction}

The complexing agent nitrilotriacetate (NTA) is used for a range of different purposes one of which is as a substitute for sodium triphosphate in laundry detergents (Tiedje 1980). Many obligately aerobic and facultatively denitrifying microorganisms have been isolated which can use NTA as a sole source of 


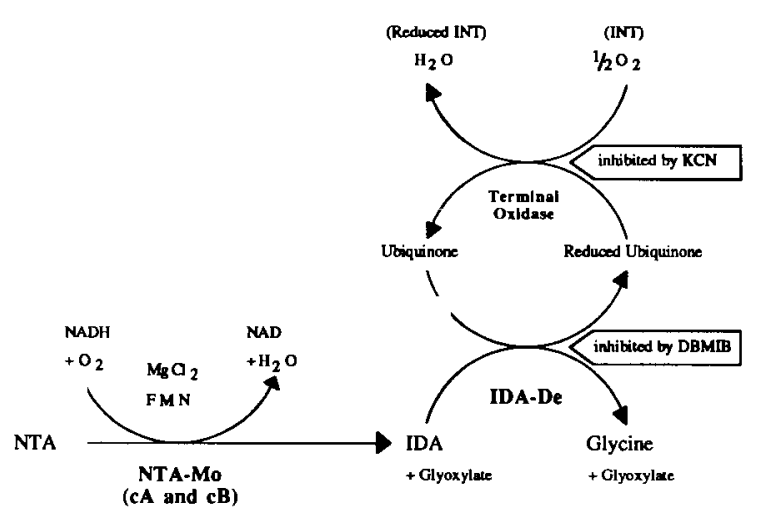

Fig. I. Metabolic pathway of NTA catalysed by NTA-MO and the membrane-bound IDA-dehydrogenase (IDA-DH) in Chelatobacter heintzii ATCC 29600.

nitrogen, carbon and energy. The majority of such isolates are Gram-negative, obligately aerobic rods (Cripps \& Noble 1973; Egli et al. 1988; Focht \& Joseph 1971; Kaki et al. 1986; Tiedje et al. 1973) which initially had been identified as Pseudomonas spp.. Recently it has been shown that these obligately aerobic isolates belong to two new genera (obligately aerobic) for which the names Chelatobacter (heintzii) and Chelatococcus (asaccharovorans) have been proposed (Auling et al. 1993).

The biochemical pathway for NTA degradation was first investigated in the two virtually identical strains of $C b$. heintzii ATCC 29600 and isolate T23 (Cripps \& Noble 1973; Firestone \& Tiedje 1978). In both strains a monooxygenase (NTA-MO) was reported to be responsible for the oxidative conversion of NTA to iminodiacetate (IDA) and glyoxylate (Fig. 1). Recently, it was possible to purify a functional NTA-MO to homogeneity from $C b$. heintzii ATCC 29600 (Uetz et al. 1992). The enzyme consisted of an NADH-oxidizing component (cB) and a second component $\mathrm{cA}$ with unknown function but necessary for the conversion of NTA to IDA and glyoxylate. The substrate specificity of NTA-MO was restricted to NTA. IDA, which was proposed to be a substrate for the NTA-MO as well (Firestone \& Tiedje 1978), was not turned over by the purified enzyme. In this paper the detection of a membrane-bound IDA dehydrogenase (IDA-DH) which converts IDA to glycine and glyoxylate is reported. Furthermore, the presence and the regula- tion of both NTA-MO and IDA-DH in differen1 NTA-utilizing strains has been investigated.

\section{Materials and methods}

Bacterial strains and growth conditions. $C b$. heintzii strains ATCC 29600 and ATCC 27109 were obtained from the American Type Culture Collection, Rockville, Md.. Isolates TE2 and TE4-TE11 were isolated in our laboratory and all strains were maintained on a synthetic medium containing $1 \mathrm{~g} \mathrm{l}^{-1}$ NTA as described previously (Egli et al.1988). In order to avoid excretion of large amounts of ammonia during large scale growth (1001) the bacteria were grown on a mixture of NTA and acetate $\left(1 \mathrm{~g} \mathrm{l}^{-1}\right.$, each). Towards the end of the exponential phase additional NTA and acetate ( $\mathrm{gl}^{-1}$, each) was added to the culture and the $\mathrm{pH}$ was kept in the range of 6.5 to 7.5 by discontinuous addition of $0.5 \mathrm{M}$ orthophosphoric acid. Cells were harvested by centrifugation at an optical density at $600 \mathrm{~nm}$ of 1.2 and the cell paste $(350 \mathrm{~g})$ was frozen at $-70^{\circ} \mathrm{C}$.

Batch growth of strain ATCC 29600 on different substrates and growth of different NTA-degrading strains on NTA was carried out in 11 Erlenmeyer flasks containing $500 \mathrm{ml}$ of medium. The medium contained $1 \mathrm{~g} \mathrm{I}^{-1}$ substrate and $0.6 \mathrm{~g} \mathrm{l}^{-1}$ of Na-acetate. Media containing $1.5 \mathrm{~g} \mathrm{I}^{-1}$ succinate or citrate, respectively, were supplemented with $1 \mathrm{~g} \mathrm{l}^{-1}$ of $\mathrm{NH}_{4} \mathrm{Cl}$ as a nitrogen source. Otherwise, the composition of the media were as described previously (Egli et al. 1988). Cells were harvested at the end of the exponential phase by centrifugation at $8000 \mathrm{~g}$ for $10 \mathrm{~min}$, resuspended in $10 \mathrm{ml} 20 \mathrm{mM}$ Tris- $\mathrm{H}_{2} \mathrm{SO}_{4} \mathrm{pH} 8.0$ and stored at $-70^{\circ} \mathrm{C}$.

Preparation of cell-free extract. $60 \mathrm{~g}$ wet weight of frozen cell paste of $C b$. heintzii strain ATCC 29600 was suspended in $400 \mathrm{ml}$ Tris- $\mathrm{HCl}$ buffer $\mathrm{pH} 8.0$ containing $2 \mathrm{mM}$ dithiothreitol, $10 \mathrm{mg}$ desoxyribonuclease I, $5 \mathrm{mM} \mathrm{MgSO}_{4}$ and the protease inhibitors leupeptin $(1 \mu \mathrm{M})$, pepstatin $(1 \mu \mathrm{M})$ and phenylmethanesulfonylfluoride $(0.5 \mathrm{mM})$ (Keesey 1987). After homogenization for 1 minute in a Sorvall homogenizer, the cells were broken by a single passage through an Aminco French press (Aminco, 
Urbana, II.) at 100MPa. EDTA was added to a final concentration of $10 \mathrm{mM}$ and the suspension was centrifuged for 30 minutes at $40000 \mathrm{~g}$ to remove unbroken cells and cell debris. Cells from the 0.51 batch cultures were broken after thawing and homogenization by a single passage through the French press in the presence of $\mathrm{MgSO}_{4}$ and desoxyribonuclease but without addition of DTT and protease inhibitors. Unbroken cells and cell debris were removed by centrifugation for $10 \mathrm{~min}$ at $12000 \mathrm{~g}$.

Preparation of membrane vesicles. The cell-free extract was centrifuged for 2 hours at $160000 \mathrm{~g}$, the supernatant (cytosolic fraction) was used for determination of NTA-MO activity. The pellet consisted of the membrane vesicles. In order to remove cytosolic proteins included in the membrane vesicles as well as the ribosomes the pellet was resuspended in $200 \mathrm{ml} 50 \mathrm{mM}$ Tris- $\mathrm{H}_{2} \mathrm{SO}_{4}$ pH $8.0,10 \%$ sucrose, $5 \mathrm{mM}$ EDTA by sonication and collected by centrifugation for 2 hours at $160000 \mathrm{~g}$. The supernatant was discarded and the pellet was resuspended by brief sonication of $20 \mathrm{ml} 50 \mathrm{mM}$ Tris- $\mathrm{H}_{2} \mathrm{SO}_{4} \mathrm{pH} 8.0$ and the washed membrane vesicles obtained by this procedure were stored in $1 \mathrm{ml}$ portions at $-70^{\circ} \mathrm{C}$. The membrane pellets, obtained from the $160000 \mathrm{~g}$ centrifugation of cell-free extracts from cells grown in shake flask batch cultures, were directly resuspended in $1 \mathrm{ml} 50 \mathrm{mM}$ Tris- $\mathrm{H}_{2} \mathrm{SO}_{4} \mathrm{pH} 8.0$ and used for experiments without applying the washing procedure.

\section{Enzyme assays}

i) NTA monooxygenase assay. NTA-MO was assayed as described previously measuring the consumption of NTA in cytosolic fractions in the presence of $\mathrm{MgCl}_{2}, \mathrm{FMN}$ and $\mathrm{NADH}$ (Uetz et al. 1992).

ii) Assay for membrane-bound dehydrogenases by oxygen consumption. Activity was determined in a closed reaction vessel $(0.8 \mathrm{ml}$ total volume $)$ fitted with a Clarke type oxygen electrode (Yellow Springs Instruments, Yellow Springs, Ohio) at $20^{\circ} \mathrm{C}$ if not otherwise stated. Membrane vesicles in $50 \mathrm{mM}$ Tris- $\mathrm{H}_{2} \mathrm{SO}_{4} \mathrm{pH} 8.0$, containing $1-4 \mathrm{mg}$ protein per $\mathrm{ml}$, were placed in the reaction vessel and the reaction was started by addition of the substrate. The decrease in oxygen concentration was recorded and the substrate dependent oxygen consumption rate was determined using a value for the concentration of $\mathrm{O}_{2}$ (air saturated) of $0.288 \mathrm{mM}$ at $20^{\circ} \mathrm{C}$ (Anonymous 1928). As only one atom of oxygen is consumed per substrate molecule used (Fig. 1 , Table 1) the value obtained was multiplied by 2 and the activity expressed as nmol substrate used per min.

iii) Assay for IDA-DH via reduction of INT. The assay was performed in $1 \mathrm{ml}$ cuvettes, containing $50 \mathrm{mM}$ Tris- $\mathrm{H}_{2} \mathrm{SO}_{4} \mathrm{pH} 8,0.2 \mathrm{mM}$ INT, $1 \mathrm{mM}$ Ubiqui-

Table 1. Stoichiometry of the reaction catalysed by the washed membrane fraction prepared from NTA-grown Cb. heintzii ATCC 29600. ${ }^{\text {a }}$

\begin{tabular}{cclllll}
\hline IDA concn (mM) & Time (min) & $\begin{array}{l}\text { IDA consumed } \\
(\mathrm{mM})\end{array}$ & $\begin{array}{l}\mathrm{O}_{2} \text { consumed } \\
(\mathrm{mM})\end{array}$ & $\begin{array}{l}\text { INT reduced } \\
(\mathrm{mM})\end{array}$ & $\begin{array}{l}\text { Glyoxylate } \\
\text { produced (mM) }\end{array}$ & $\begin{array}{l}\text { Glycine produced } \\
(\mathrm{mM})\end{array}$ \\
\hline 10 & 4.5 & n.d. & 0.26 & & 0.53 & 0.55 \\
10 & 9 & n.d. & n.d. & 0.94 & 1.12 \\
10 & 14 & n.d. & n.d. & & 1.52 & 1.56 \\
2 & 0 & 0 & 0 & 0.01 & 0.01 \\
2 & 10 & 0.54 & 0.23 & 0.82 & 0.50 & 0.42 \\
$2^{\text {b }}$ & 10 & 0.41 & 0 & n.d. & 0.46 \\
\hline
\end{tabular}

\footnotetext{
${ }^{a}$ The reaction vessel contained washed membranes $\left(0.65 \mathrm{mg}\right.$ protein $\left.\mathrm{ml}^{-1}\right)$ in $50 \mathrm{mM}$ ammonium acetate at pH 8.0 . In a control experiment containing protein denatured with heat $\left(10 \mathrm{~min}\right.$ at $\left.95^{\circ} \mathrm{C}\right)$ neither IDA nor oxygen was consumed and neither glyoxylate nor glycine was formed.

${ }^{b}$ The reaction was carried out in the presence of $1 \mathrm{mM} \mathrm{KCN}$. n.d. Not determined.
} 
none $\mathrm{Q}_{1}, 50 \mathrm{mM} \mathrm{CaCl}$ and $42 \mathrm{mM}$ IDA (from a stock solution of $0.84 \mathrm{M}$ at $\mathrm{pH} 9.5$ ). Approximately $0.1 \mathrm{mg}$ protein was added to start the reaction and the change in absorption at $500 \mathrm{~nm}$ was recorded against a reference cuvette containing all ingredients except IDA. No reduction of INT was observed in the reference cuvette. Activity was calculated as nmol INT reduced per min using a molar extinction coefficient of reduced INT $\varepsilon_{500}=$ $11100 \mathrm{~cm}^{-1} \mathrm{~mol}^{-1}$, which was determined by the complete reduction of $0.1 \mathrm{mM}$ INT with $1 \mathrm{mM}$ DTT.

Analysis of NTA and succinate. To measure NTA in cell-free extracts TCA was added to samples to a final concentration of $5 \%(\mathrm{v} / \mathrm{v})$ and precipitated protein was removed by centrifugation for $5 \mathrm{~min}$ at $10000 \mathrm{~g}$. For the determination of substrate concentrations in growing cultures, the cells were removed from $1 \mathrm{ml}$ samples by centrifugation for $2 \mathrm{~min}$ at $15000 \mathrm{~g}$ and dilution of the supernatant 1 to $10 \mathrm{in}$ water before analyzing for NTA and succinate by high pressure ion exclusion chromatography as described by Schneider et al. (1988).

Analysis of IDA. IDA was determined by a modified procedure of Schneider et al. (1989). The sample $(100 \mu \mathrm{g})$ was mixed with $200 \mu \mathrm{l} 30 \mathrm{mM} \mathrm{H}_{3} \mathrm{PO}_{4}$, boiled for $5 \mathrm{~min}$ and the precipitated protein was removed by centrifugation. The supernatant $(215 \mu \mathrm{l})$ was mixed with $500 \mu \mathrm{l} \mathrm{H}_{2} \mathrm{O}$ before analysis. Separation was achieved on a Dionex AS4A column using $2 \mathrm{mM}$ tyrosine in $4.5 \mathrm{mM} \mathrm{NaOH}$ as the eluent with a Dionex 2000i high pressure chromatography system connected to a Dionex CDM2 conductivity detector (Dionex, Sunnyvale, CA).

Analysis of glyoxylate. Prior to analysis of glyoxylate, samples of $100 \mu \mathrm{l}$ were mixed with $40 \mu \mathrm{l}$ of $67 \mathrm{mM} \mathrm{HCl}$ to stop IDA-DH activity. The amount of glyoxylate in the sample was analyzed with the phenylhydrazine/ $\mathrm{K}_{3} \mathrm{Fe}(\mathrm{CN})_{6}$ method described by Trijbels \& Vogels (1966), but using a total assay volume of $280 \mu 1$.

Analysis of glycine. Prior to analysis, samples of $100 \mu \mathrm{l}$ were mixed with an equal volume of $2 \%(\mathrm{v} / \mathrm{v})$ trifluoracetic acid and precipitated protein was removed by centrifugation for $2 \mathrm{~min}$ at $15000 \mathrm{~g}$. A $100 \mu \mathrm{l}$ aliquot of the supernatant was freeze dried to remove volatile compounds, redissolved in $1 \mathrm{ml} \mathrm{Na-}$ nopur water and analysed for glycine as described by Knecht \& Young (1986).

Protein determination. Protein concentrations were measured using the BCA (Bicinchoninic acid) protein assay (Pierce, Rockford, IL). Bovine serum albumin was used as the standard. For determination of protein concentration during solubilization and reconstitution of IDA-DH, a modified Lowry method was used (Peterson 1979).

Solubilization of IDA-DH. To $2.4 \mathrm{ml}$ of a suspension of membrane vesicles in $50 \mathrm{mM}$ Tris- $\mathrm{H}_{2} \mathrm{SO}_{4} \mathrm{pH} 8.0$, containing $10-20 \mathrm{mg}$ protein per $\mathrm{ml}$ and $1 \mathrm{mM}$ phenylmethanesulfonylfluoride, $0.8 \mathrm{ml}$ of $50 \%$ glycerol (v/v) was added. Whilst the suspension was stirred at $4^{\circ} \mathrm{C} 0.8 \mathrm{ml}$ of a $10 \%(\mathrm{w} / \mathrm{v}) \mathrm{Na}$-cholate solution containing $2 \%$ soybean phospholipids, was added dropwise to give a final concentration of $2 \%$ cholate. After $20 \mathrm{~min}$ stirring at $4^{\circ} \mathrm{C}$, the suspension was centrifuged for $50 \mathrm{~min}$ at $250000 \mathrm{~g}$ and the supernatant was referred to as solubilized membrane proteins. Solubilization of IDA-DH activity was unsuccessful with the following detergents: $1 \%$ Lubrol, $1 \%$ octyl-PoE, $1 \%$ deoxycholate, $1 \%$ Triton-X-100, 1\% CHAPS (3-(3-cholamidopropyl)dimethyl-ammonio-1-propane sulfonate), $0.4 \%$ dodecyl maltoside and $1 \%$ octylglucoside.

Reconstitution of IDA-DH activity in artificial soybean phospholipid vesicles. A modified procedure described by Varadhachary \& Maloney (1990) was used to reconstitute IDA-DH from the solubilized membrane protein fraction in artificial soybean phospholipid vesicles. A suspension of $4 \%(w / v)$ soybean phospholipids in $2 \%$ Na-cholate was prepared by sonication and $1 \mathrm{ml}$ thereof was mixed with $3 \mathrm{ml}$ of the solubilized membrane protein fraction. After $20 \mathrm{~min}$ gentle shaking at $4^{\circ} \mathrm{C}$ followed by $30 \mathrm{~s}$ of mild sonication the mixture was rapidly diluted by addition of $80 \mathrm{ml}$ of cold $50 \mathrm{mM}$ Tris- $\mathrm{H}_{2} \mathrm{SO}_{4}(\mathrm{pH}$ $8.0)$ solution. After $30 \mathrm{~min}$ the slightly turbid sus- 
pension was centrifuged for $2 \mathrm{~h}$ at $160000 \mathrm{~g}$ and the pellet was resuspended in $2 \mathrm{ml} 50 \mathrm{mM}$ Tris- $\mathrm{H}_{2} \mathrm{SO}_{4}$ $\mathrm{pH} 8.0$ by brief sonication.

\section{Preparation of antisera. Antisera against $\mathrm{cA}$ and $\mathrm{cB}$} of NTA-MO from $C b$. heintzii ATCC 29600 were prepared as described previously (Uetz et al. 1992). Specificity of the two antisera was tested by using the immunoblotting technique described below. None of the sera reacted against proteins of cellfree extracts from succinate-grown $C b$. heintzii ATCC 296000 (T. Uetz 1992).

\section{Immunodetection of the two NTA-MO components.} Protein samples were run on $12 \%$ SDS-PAGE gels (Laemmli 1970) and blotted onto a nitrocellulose sheet following the method of Towbin et al. (1979). The nitrocellulose sheet was incubated in $20 \mathrm{ml}$ PBS (phosphate buffered saline; $100 \mathrm{mM} \mathrm{K}-\mathrm{PO}_{4}, \mathrm{pH} 7.2$, $150 \mathrm{mM} \mathrm{NaCl}$ ) containing 4\% PVP (Polyvinylpyrrilidone) for $2 \mathrm{~h}$. Subsequently it was incubated in $20 \mathrm{ml}$ PBS containing 2\% PVP, $10 \mu \mathrm{l}$ antiserum against $\mathrm{cA}$ and $10 \mu \mathrm{l}$ antiserum against $\mathrm{cB}$ for $1 \mathrm{~h}$. This was followed by extensive washing with PBS containing 2\% PVP and incubation in PBS containing $2 \%$ PVP and $1 \mu$ Curie of ${ }^{125}$ I-labeled protein A for $45 \mathrm{~min}$ (Harlow \& Lane 1988). After washing the sheet with PBS and drying, it was exposed for 60 hours to a Fuji RX medical X-ray film.

Chemicals. Ubiquinone $\mathrm{Q}_{1}$ was a gift from Dr. U. Fischer of Hoffmann-La Roche, Basel, Switzerland. Catalase, desoxyribonuclease I, dithiothreitol and phenylmethanesulfonylfluoride were obtained from Serva, Heidelberg, FRG. Leupeptin and pepstatin were products of Boehringer, Mannheim, FRG. N-methylated amino acids, soybean phospholipids, Antimycine, DBMIB and ubiquinone $\mathrm{Q}_{10}$ were supplied from Sigma, St. Louis, MO. All other chemicals were of analytical grade and were obtained from either Fluka, Buchs, Switzerland or Merck, Darmstadt, FRG.

\section{Results}

Oxidation of IDA by washed membrane preparations from Chelatobacter heintzii ATCC 29600. In the search for an enzyme, able to transform IDA, it was found that IDA stimulated oxygen consumption of membrane preparations obtained from NTA-grown cells of $C b$. heintzii ATCC 29600. No IDA-stimulated oxygen consumption was observed in the soluble protein fraction from such cells. IDA not only stimulated oxygen consumption in the membrane preparation, but it was oxidized stoichiometrically to glyoxylate and glycine at the expense of half a molecule of $\mathrm{O}_{2}$ (Table 1). When the reduction of $\mathrm{O}_{2}$ was inhibited by $\mathrm{KCN}$, or in the absence of oxygen, artificial electron acceptors such as DCPIP or INT were reduced instead of $\mathrm{O}_{2}$ (Table 1). This suggested, that washed membrane vesicles catalysed the oxidation of IDA according to the scheme given in Fig. 1.

Specificity of IDA-DH and its biochemical distinction from the membrane-bound succinate dehydrogenase. None of the following compounds were able to significantly stimulate oxygen consumption in the membrane preparations from NTA-grown cells: glycine, glyoxylate, dimethylglycine, NTA, trimethylamine, dimethylamine, methylamine, $\mathrm{N}$-methylglutamate, L-proline, L-glutamate, L-aspartate, $\mathrm{N}$ hydroxyethyl-IDA, $\mathrm{N}$-methyl-IDA, phenylalanine, DL-alanine, glutarate and glyphosate. $\mathrm{N}$-methylalanine, $\mathrm{N}$-methylphenylalanine, $\mathrm{N}$-methylleucine and sarcosine stimulated oxygen consumption only up to a maximum of $2.5 \%$ of the rate observed for IDA. Succinate significantly stimulated oxygen consumption of washed membranes but, in contrast to IDA oxidation, this activity was completely inhibited by $15 \mathrm{mM}$ malonate. Furthermore, membranes from succinate-grown cells did not exhibit IDA oxidation, whereas succinate was oxidized at a similar rate as in membranes from NTA-grown cells (see also Table 5).

Characterization of the membrane-bound IDA-DH activity. Because IDA is able to chelate metal ions it was investigated, whether some of these ions could 
stimulate IDA oxidation. Furthermore, some compounds known to interact with components of the bacterial electron transport chain were tested for their ability to inhibit IDA oxidation. Table 2 summarizes the results obtained with washed membranes from NTA-grown cells. IDA oxidation was increased in the presence of $\mathrm{CaCl}_{2}, \mathrm{BaCl}_{2}$ and $\mathrm{MgCl}_{2}$. Furthermore, the $\mathrm{K}_{\mathrm{m}}$ value for IDA was $8 \mathrm{mM}$ in the presence of $\mathrm{CaCl}_{2}$, compared to $50 \mathrm{mM}$ in its absence. Other divalent cations tested inhibited oxygen consumption either slightly $\left(\mathrm{MnCl}_{2}\right.$ and $\left.\mathrm{FeCl}_{3}\right)$ or completely $\left(\mathrm{ZnCl}_{2}, \mathrm{CuCl}_{2}\right.$ and $\left.\mathrm{NiCl}_{2}\right)$. EDTA did not inhibit oxygen consumption, which indicated that IDA oxidation was not strictly dependent on metal ions. IDA oxidation was very sensitive to $\mathrm{KCN}$, but under these conditions rapid reduction of the artificial electron acceptor INT was possible. DBMIB, which is an ubiquinone analog and was reported to inhibit reoxidation of ubiquinones (Crofts \& Wraight 1983), inhibited both IDA-stimulated oxygen consumption and IDA-dependent INT reduction (Table 2). This was also the case for antimycin A which blocks electron transfer from b-type cytochromes (Crofts et al. 1983; Crofts \& Wraight 1983).

The $\mathrm{pH}$ optimum and the temperature optimum of the membrane-bound IDA dehydrogenase were determined to be 8.2 and $28^{\circ} \mathrm{C}$, respectively. The enzyme was active in a rather broad range of $\mathrm{pH}$ values $(50 \%$ of maximum activity at $\mathrm{pH} 6.9$ and 9.2 , respectively) and temperatures (50\% of maximum activity at $14^{\circ} \mathrm{C}$ and $38^{\circ} \mathrm{C}$, respectively). At $\mathrm{pH}$ values below 5 and above 11 activity was irreversively lost, as was the case for temperatures above $45^{\circ} \mathrm{C}$.

Solubilization and reconstitution of IDA-DH activity. A range of detergents (see 'Materials and methods') was tested for extraction of IDA-dehydrogenase from washed membranes. Activity of solubilized IDA-DH was determined by following INT reduction using different possible intermediate electron acceptors (PMS, ubiquinone $\mathrm{Q}_{0}$ and ubiquinone $Q_{1}$ ). Only when $1 \%$ or $2 \%$ cholate was used for solubilization and ubiquinone $Q_{1}$ (to a lesser extent ubiquinone $\mathrm{Q}_{0}$ ) as an intermediate electron carrier in the assay was significant IDA-dependent INT reduction observed in the solubilized mem- brane protein fraction. However, the amount of solubilized activity never exceeded $10 \%$ of the observed activity in the membranes (Table 3 ). The extracted membranes in the pellet never contained more than $10 \%$ of the original IDA-dependent INT-reducing activity. The solubilized membrane protein fraction was devoid of IDA-stimulated oxygen consumption activity, showing that the preparation was not contaminated with intact membrane vesicles. These results suggest that, to be active, IDA-DH has to be integrated in a phospholipid bilayer. Therefore, an attempt to reconstitute IDA-DH activity in artificial soybean phospolipid vesicles, by a

Table 2, Stimulation and inhibition of the membrane-bound IDA-DH from $C b$. heintzii ATCC 29600.

\begin{tabular}{ll}
\hline Added compound (conen in $\mathrm{mM})^{\mathrm{a}}$ & $\begin{array}{l}\text { Assay Relative } \\
\text { method }^{\mathrm{b}} \text { activity }\end{array}$
\end{tabular}

(\%)

\begin{tabular}{llr}
\hline $\mathrm{Control}^{\mathrm{c}}$ & $\mathrm{O}_{2}$ & 100 \\
$\mathrm{CaCl}_{2}(20)$ & $\mathrm{O}_{2}$ & 200 \\
$\mathrm{BaCl}_{2}(20)$ & $\mathrm{O}_{2}$ & 214 \\
$\mathrm{MgCl}_{2}(20)$ & $\mathrm{O}_{2}$ & 141 \\
$\mathrm{MnCl}_{2}(20)$ & $\mathrm{O}_{2}$ & 39 \\
$\mathrm{FeCl}_{3}(20)$ & $\mathrm{O}_{2}$ & 68 \\
$\mathrm{CuCl}_{2}(20)$ & $\mathrm{O}_{2}$ & 0 \\
$\mathrm{NiCl}_{2}(20)$ & $\mathrm{O}_{2}$ & 5 \\
$\mathrm{ZnCl}_{2}(20)$ & $\mathrm{O}_{2}$ & 0 \\
$\mathrm{EDTA}(20)$ & $\mathrm{O}_{2}$ & 107 \\
$\mathrm{CaCl}_{2}(20)+\mathrm{KCN}(1)$ & $\mathrm{O}_{2}$ & 0 \\
$\mathrm{CaCl}_{2}(20)+\mathrm{KCN}(0.1)$ & $\mathrm{O}_{2}$ & 8 \\
$\mathrm{CaCl}_{2}(20)+\mathrm{KCN}(0.01)$ & $\mathrm{O}_{2}$ & 23 \\
$\mathrm{CaCl}_{2}(20)+\mathrm{KCN}(0.1)=$ Control & INT & 100 \\
$\mathrm{CaCl}_{2}(20)+$ Antimycine $(0.5)$ & $\mathrm{O}_{2}$ & 2 \\
$\mathrm{CaCl}_{2}(20)+\mathrm{KCN}(0.1)+$ Antimycine $(0.5)$ & INT \\
$\mathrm{CaCl}_{2}(20)+\mathrm{DBMIB}(0.5)$ & $\mathrm{O}_{2}$ & 0 \\
$\mathrm{CaCl}_{2}(20)+\mathrm{KCN}(0.1)+$ DBMIB $(0.5)$ & $\mathrm{INT}$ & \\
\hline
\end{tabular}

These compounds were present in the assay in addition to those present in the control experiment. The figure in brackets gives the final concentration ( $\mathrm{mM}$ ) of the added compound.

${ }^{\text {h}}$ Either the oxygen consumption assay $\left(\mathrm{O}_{2}\right)$ or the INT reduction assay (INT) was used to determine the activity.

'The control assay contained in $1 \mathrm{ml}$ of $50 \mathrm{mM}$ Tris- $\mathrm{H}_{2} \mathrm{SO}_{4}$ buffer at $\mathrm{pH} 8.0,42 \mathrm{mM}$ IDA, and washed membranes $(1.3 \mathrm{mg}$ protein with a specific activity of $184 \mathrm{nmol}$ IDA $\mathrm{min}^{-1}(\mathrm{mg} \text { protein })^{-1}$ in the presence of $\mathrm{CaCl}_{2}$ ).

${ }^{\mathrm{d}}$ The control assay contained in $1 \mathrm{ml}$ of $50 \mathrm{mM}$ Tris- $\mathrm{H}_{2} \mathrm{SO}_{4}$ buffer at $\mathrm{pH} 8.0,42 \mathrm{mM}$ IDA, $2 \mathrm{mM}$ INT and washed membranes

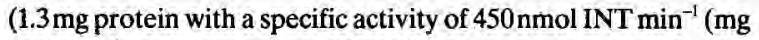
protein) $)^{-t}$ in the presence of $\mathrm{CaCl}_{2}$ ). 
modified method described by Varadhachary \& Maloney (1990) was made. The specific IDA-DH activity increased 10 -fold by this treatment with a recovery of $50 \%$ (Table 3 ). Reconstitution of IDADH activity in the presence of $1 \mathrm{mM}$ ubiquinone- $Q_{10}$, which is the major ubiquinone found in this genus (Auling et al. 1993), led to a recovery of $58 \%$ of IDA-DH activity (Table 3 ).

\section{Characterization of reconstituted IDA-DH activity} of soybean phospholipid vesicles. Ubiquinone $\mathrm{Q}_{10^{-}}$ free phospholipid vesicles containing reconstituted IDA-DH activity were devoid of IDA-stimulated oxygen consumption activity and only weak INT reduction (5\%) was observed in the absence of added ubiquinone- $Q_{1}$. Whereas, when IDA-DH was reconstituted in ubiquinone- $Q_{10}$ containing phospholipid vesicles some oxygen consumption activity, which was inhibited in the presence of $\mathrm{KCN}$ and considerable INT reduction activity $(40 \%)$ was observed without ubiquinone- $Q_{1}$ being present in the assay. This strongly suggests that in vivo ubiquinone- $Q_{10}$ acts as an electron acceptor for IDA-DH. IDA-DH reconstituted in ubiquinone- $Q_{10}$-free phospholipid vesicles was used for a detailed characterization of the enzyme (Table 4). Reduction of INT was stimulated by the addition of a soluble

Table 3. Solubilization and reconstitution of IDA-DH from Chelatobacter heintzii ATCC 29600 in phospholipid vesicles.

\begin{tabular}{lcccc}
\hline Step & $\begin{array}{l}\text { Total } \\
\text { protein } \\
(\mathrm{mg})\end{array}$ & $\begin{array}{l}\text { Total } \\
\text { activity } \\
\left({ }^{\mathrm{a}}\right)\end{array}$ & $\begin{array}{l}\text { Specific } \\
\text { activity } \\
\left({ }^{\mathrm{b}}\right)\end{array}$ & $\begin{array}{l}\text { Recovery } \\
(\%)\end{array}$ \\
\hline Washed membranes & 30 & 13500 & 450 & 100 \\
Remaining membranes & 9.3 & 1270 & 136 & 8 \\
$2 \%$ Cholate extract & 17.8 & 940 & 53 & 7 \\
Reconstituted IDA-DH & 8.4 & 4500 & 540 & 38 \\
Reconstituted IDA-DH & & & & \\
$\left(+\mathrm{Q}_{10}\right)^{\mathrm{c}}$ & 8.6 & 6840 & 795 & 58 \\
\hline
\end{tabular}

(Specific) activity was expressed as nmol INT reduced min $^{-1}$ (mg protein) ${ }^{-1}$.

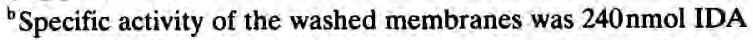
$\mathrm{min}^{-1}$ (mg protein $)^{-1}$ determined in the oxygen consumption assay.

'Soybean phospholipids suspensions used for the reconstitution of IDA-DH were prepared in the presence of $1 \mathrm{mM}$ ubiquinone $\mathrm{Q}_{10}$
Table 4. Characterization of IDA-DH from Chelatobacter heintzii ATCC 29600 reconstituted in phospholipid vesicles.

\begin{tabular}{lc}
\hline Added compound (concn in $\mathrm{mM})^{\mathrm{a}}$ & $\begin{array}{l}\text { Relative } \\
\text { activity } \\
(\%)\end{array}$ \\
\hline Control $^{b}$ & 5 \\
Control + Ubiquinone $\mathrm{Q}_{1}(1)$ & 100 \\
Control + Ubiquinone $\mathrm{Q}_{0}(1)$ & 22 \\
Control + Duroquinone (1) & 4 \\
Control + Menadione (1) & \\
Control + Phenazine methosulfate (1) & 0 \\
Control + Ubiquinone $\mathrm{Q}_{1}(1)+$ Antimycine $(0.5)$ & \\
Control + Ubiquinone $\mathrm{Q}_{1}(1)+$ DBMIB (0.5) &
\end{tabular}

The compounds indicated were present in the assay in addition to those present in the control experiment. The figure in brackets gives the final concentration ( $\mathrm{mM}$ ) of the added compound.

${ }^{\text {n}}$ The control assay contained in $1 \mathrm{ml}$ of $50 \mathrm{mM}$ Tris- $\mathrm{H}_{2} \mathrm{SO}_{4}$ buffer (pH 8.0), 25 mM CaCl, $42 \mathrm{mM}$ IDA, $2 \mathrm{mM}$ INT and reconstituted IDA-DH ( $168 \mu \mathrm{g}$ protein with a specific activity of $540 \mathrm{nmol}$ INT reduced $\min ^{-1}$ ( $\mathrm{mg}$ protein $)^{-1}$ ).

ubiquinone, either $\mathrm{Q}_{0}$ or $\mathrm{Q}_{1}\left(\mathrm{~K}_{\mathrm{m}}\right.$ value for ubiquinone $Q_{1}$ was $\left.1 \mathrm{mM}\right)$. Other electron acceptors such as duroquinone, menadione or PMS were ineffective. IDA-DH activity was strongly inhibited by DBMIB, which blocks electron transfer to ubiquinones (Crofts \& Wraight 1983), and by antimycin A, which was reported to inhibit electron transfer to

Table 5. Specific activities of NTA-MO, IDA-DH and Suc-DH in cells of Chelatobacter heintzii ATCC 29600 grown on different substrates.

\begin{tabular}{ll}
\hline Growth & Specific activities [nmol substrate $\mathrm{min}^{-1}(\mathrm{mg}$ \\
substrate & protein $)^{-1}$ ] of:
\end{tabular}

NTA-MO IDA-DH Suc-DH Sarcosine-DH

\begin{tabular}{llccc}
\hline Succinate & $<1$ & $<1$ & 39 & $<1$ \\
NTA & 353 & 145 & 28 & $<1$ \\
IDA & 226 & 52 & 38 & $<1$ \\
Dimethylglycine & $<1$ & $<1$ & 97 & 60 \\
Dimethylamine & $<1$ & $<1$ & 28 & n.d.
\end{tabular}

Neither NTA-MO activity nor IDA-DH activity was observed in extracts from cells that were grown on acetamide, choline, citrate, complex medium, glutamate, glycine, glycylglycine, glyoxylate, histidine, hypoxantine, methylamide, phenylalanine, proline, putrecine, thymine, trimethylamine, or threonine. n.d. $=$ Not determined. 
type-b cytochromes (Crofts et al. 1983; Crofts \& Wraight 1983). However, no inhibition of INT reduction was observed in the presence of $1 \mathrm{mM} \mathrm{KCN}$, which inhibits electron transfer to oxygen at the level of the terminal oxidase.

Specific activities of IDA-DH and Suc-DH in membranes from $\mathrm{Cb}$. heintzii ATCC 29600 . To confirm the involvement of IDA-DH in the biodegradation of NTA to glycine and glyoxylate, $C b$. heintzii ATCC 29600 was grown for five successive transfers (batch cultures) on succinate and ammonia followed by two transfers on the new substrate. From these cells, membrane fractions were tested for IDA-DH and Suc-DH activity and the cytosolic fractions were examined for NTA-MO activity ( $\mathrm{Ta}$ ble 5). Under all growth conditions membrane fractions contained Suc-DH activity, which was completely inhibited by $15 \mathrm{mM}$ malonate. However, IDA-DH activity was only detected, when the bacteria were grown on either NTA or IDA. Similarly, NTA-MO was only expressed in cells grown on NTA or IDA. When the bacteria were grown on dimethylglycine or choline, membrane-bound activity of sarcosine dehydrogenase was observed. No membrane-bound $\mathrm{N}$-methylglutamate dehydrogenase, as described by Bamforth \& Large (1977) was present in membranes prepared from methylamine-, dimethylamine- or trimethylamine-grown cells.

\section{Induction of IDA-DH in cells growing exponentially} on succinate and ammonia. In order to investigate whether IDA-DH would be expressed in cells growing exponentially on a substrate other than IDA or NTA, $C b$, heintzii ATCC 29600 was grown in batch culture with succinate and ammonia and $0.4 \mathrm{~g}$ NTA $\mathrm{I}^{-1}$ were pulsed to the exponentially growing culture (Fig. 2A). After a short lag succinate was utilized by the cells at a similar rate as before NTA addition. Four hours after the pulse a significant amount of NTA was already utilized and after 8 hours NTA was consumed to completion. IDA-DH (Fig. 2B) and the two components of the NTA-MO (Fig. 2C) were induced within the first hour after NTA addition, whereas the specific activity of Suc-DH was
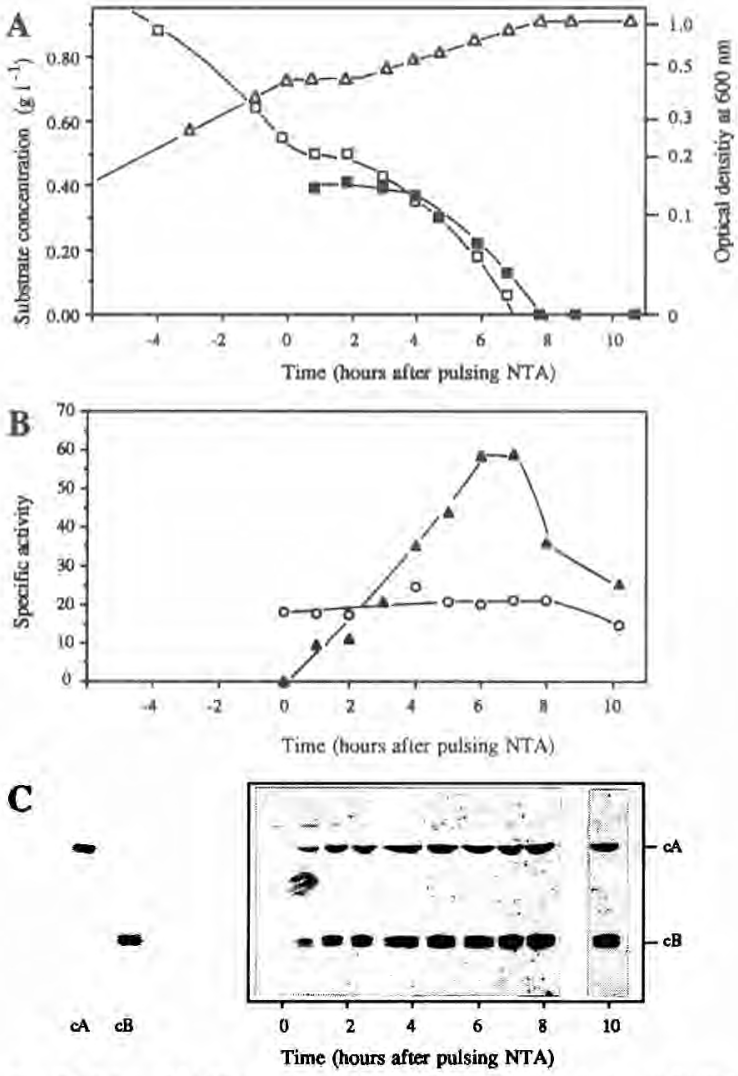

Fig. 2. Pulse of NTA to a culture of Chelatobacter heintzii ATCC 29600 growing exponentially in batch culture with succinate and ammonia.

A) Growth $\left(\mathrm{OD}_{600}\right)$ and concentration of substrates as a function of time. At time zero $0.4 \mathrm{gl}^{-1} \mathrm{NTA}$ was added to the culture medi$u m$. The symbols represent $\mathrm{OD}_{600}(\Delta)$, the concentration of succinate ( $\square$ ) and NTA (ש).

B) Specific activity of membrane-bound IDA-DH (A) before and after NTA addition. The specific activity of Suc-DH $(\triangleright)$ was measured as a control. Specific activity is given in nmol substrate $\min ^{-1}$ (mg protein) $)^{-1}$.

C) Immunoblot of the two components $\mathrm{cA}$ and $\mathrm{cB}$ of NTA-MO. $34 \mu \mathrm{g}$ protein from the cytosolic fraction were separated on SDSPAGE and the two components of the NTA-MO were detected immunologically. $0.8 \mu \mathrm{g}$ of purified $\mathrm{cA}$ and $\mathrm{cB}$, respectively, from $C b$. heintzii ATCC 29600 were included as standards.

not influenced by pulsing NTA to the culture (Fig. 2B).

Membrane-bound IDA-DH in other NTA-degrading bacteria. In order to investigate whether an inducible membrane-bound IDA-DH was also present in other NTA-degrading bacteria, membrane 
fractions of nine bacterial strains from three different genera were examined and tested for IDA-DH and Suc-DH activity (Table 6). Both IDA-DH and Suc-DH activity were found in all strains tested. In membrane preparations from cells grown on glycine as a control experiment, Suc-DH activity (completely inhibited by $15 \mathrm{mM}$ malonate) but no IDADH activity was found. In all strains tested IDADH was active in the presence of $15 \mathrm{mM}$ malonate, but it was completely inhibited by $0.5 \mathrm{mM} \mathrm{KCN}$. When inhibited by cyanide, membrane-bound IDA-DH from all strains catalyzed the rapid reduction of INT. Furthermore, NTA-MO activity was observed in the cytosolic fraction of eight out of nine strains when they were grown on NTA (Table 6). In the strain not exhibiting NTA-MO activity a PMS-dependent NTA dehydrogenase was found (Kemmler 1992).

\section{Discussion}

Two different enzymes are presently known to cleave NTA oxidatively, NTA monooxygenase and NTA dehydrogenase (Egli et al. 1990). Both enzymes have been purified and characterized extensively (Jenal-Wanner 1991; Kemmler 1992; Uetz et al. 1992) and for both enzymes the products formed from NTA were IDA and glyoxylate. In contrast to earlier reports which suggested that NTA-MO might be involved in the subsequent oxidation of IDA (Firestone \& Tiedje 1978), neither enzyme was reported to exhibit activity with IDA.

The data reported here demonstrate that in all the presently known Gram-negative NTA-degrading bacteria IDA is metabolized by a membranebound IDA-DH. This enzyme is of considerable importance in the biodegradation of NTA because accumulation of IDA in the natural environment would be unfavorable because of the possible formation of putatively cancerogenic N-nitroso-IDA from IDA and nitrite (Epstein 1972; Pickaver 1976).

As with NTA-MO and NTA dehydrogenase, the substrate specificity of IDA-DH appears to be very narrow. Presently IDA is the only known substrate and IDA-DH exhibited no significant activity with several structurally similar compounds, such as succinate, glutarate, $\mathrm{N}$-methylglutamate, $\mathrm{N}$-methylIDA and sarcosine. Nevertheless, the high $\mathrm{K}_{\mathrm{m}}$ value ( $8 \mathrm{mM}$ ) observed for $\mathrm{Ca}^{2+}$ complexed IDA suggests that either the protein has evolved from an already existing protein or that IDA is not the natural substrate for this enzyme. From the structural resemblence of the substrates both sarcosine dehydroge-

Table 6. Occurence of IDA-DH and NTA-MO in nine different NTA-degrading strains.

\begin{tabular}{|c|c|c|c|c|}
\hline \multirow[t]{2}{*}{ Genus } & \multirow[t]{2}{*}{ Strain } & \multicolumn{3}{|c|}{ Specific activities ${ }^{\text {a }}$ [nmol substrate $\min ^{-1}$ (mg protein $)^{-1}$} \\
\hline & & IDA-DH & Suc-DH & NTA-MO \\
\hline Chelatococcus asaccharovorans & TE 2 & 32 & 30 & 26 \\
\hline \multirow[t]{7}{*}{ Chelatobacter heintzii } & ATCC 29600 & 25 & 22 & 148 \\
\hline & TE 4 & 7.5 & 7.5 & 168 \\
\hline & TE 5 & 15 & 9.4 & \\
\hline & TE 6 & 28 & 10 & 118 \\
\hline & TE 7 & 23 & 6.3 & 152 \\
\hline & TE 8 & 8.5 & 6.5 & \\
\hline & TE 10 & 40 & 14 & 120 \\
\hline Unidentified genus $^{c}$ & TE 11 & 10 & 13.3 & $<5^{b}$ \\
\hline
\end{tabular}

aspecific activity of IDA-DH was determined using the oxygen consumption assay in the presence of $20 \mathrm{mM} \mathrm{CaCl}_{2}$.

${ }^{6}$ A PMS-dependant NTA dehydrogenase, as reported by Kemmler (Kemmler 1992), was present in the cytosolic fraction.

'Strain TE 11 was characterized by (Wanner et al.1990). This strain probably belongs to a new genus within the $\gamma$-subgroup the Proteobacteria. 
nase and Suc-DH are two potential candidates. However, in addition to the fact that neither enzyme accepted IDA as a substrate (Table 5) and that they were not induced either by NTA or by IDA, they also differ structurally from IDA-DH. By applying the method described by Reddy \& Weber (1986), it was found that IDA-DH, sarcosine dehydrogenase and Suc-DH differ in their mobility on native polyacrylamide gels (T. Uetz \& T. Egli unpubl.).

The fact that IDA-DH was present in the particulate fraction of cell-free extracts, that its activity was linked to the respiratory chain and that IDADH activity could only be solubilized by using detergents, demonstrates that it forms an integral protein complex in the membrane. From this one can conclude that IDA-DH is clearly distinct from other soluble dehydrogenases such as N-methylglutamate dehydrogenase (Bamforth \& Large 1977; Boulton et al. 1980), dimethylamine dehydrogenase, trimethylamine dehydrogenase (Kasprzak et al. 1983; Meiberg \& Harder 1979), and from dehydrogenases that are only loosely associated with the cytoplasmic membrane, such as sarcosine dehydrogenase, choline dehydrogenase and D-alanine dehydrogenase from Pseudomonas aeruginosa (Bater \& Venables 1977). Many membrane-bound dehydrogenases have been described in the literature which have ubiquinones as natural electron acceptors. However, in contrast to IDA-DH, all these dehydrogenases were able to reduce PMS after solubilization with detergents and activity was not reduced after solubilization. For the majority of those dehydrogenases partial or complete purification was therefore possible (Ingledew \& Poole 1984; Matsushita et al. 1987; Olsiewski et al. 1980; Pennoyer et al. 1988; Tushurashavili et al. 1985). Others consisted of large complexes and purification turned out to be difficult, as it was reported for succinate dehydrogenase from $E$. coli (Kita et al. 1989) or Nmethylglutamate dehydrogenase from Pseudomonas aminovorans (Bamforth \& Large 1977). The latter two enzymes contained b-type cytochromes. This also seems to be the case for IDA-DH, because IDA-DH reconstituted in soybean phospholipids was sensitive to antimycin A. Further indication for the presence of a b-type cytochrome in IDA-DH was obtained from preliminary difference spectra, where an IDA-reduced reconstituted solubilized IDA-DH versus an oxidized control exhibited a maximum at $560 \mathrm{~nm}$ with a shoulder at approximately 580nm (T. Uetz \& T. Egli unpubl.). This, however, remains to be confirmed by partial or complete purification of IDA-DH.

An interesting aspect of NTA degradation by $C b$. heintzii ATCC 29600 is its regulation. Although this bacterium is able to grow on a large variety of substrates as a sole source of carbon, nitrogen and energy (Egli et al. 1988) none of the various substrates tested other than NTA or IDA led to the induction of either NTA-MO or IDA-DH, not even when the substrates were structurally closely related to NTA and IDA. The fact that the two enzymes were induced within one hour after NTA was pulsed to a culture growing exponentially on succinate and ammonia, suggests that NTA and IDA (or metabolites thereof) function as inducer molecules, which leds to de novo synthesis of NTA-MO and probably also of IDA-DH. Nevertheless, with respect to the regulation of enzymes involved in the metabolism of NTA several ecological aspects remain to be investigated. For example, it would be interesting to know whether the NTA-degrading enzymes are also expressed under environmentally relevant conditions, e.g. during growth at low substrate concentrations with mixtures of carbon/nitrogen sources including NTA or IDA. This challenging question concerning inducibility of NTA-MO and IDA-DH in ecosystems could be investigated using the membrane diffusion chamber technique as described by McFeters et al. (1990), where pure cultures of bacteria can be exposed to river water or wastewater. Preliminary experiments have already shown that Cb. heintzii ATCC 29600 , pre-grown in the laboratory under non-inducing conditions, was able to catabolize NTA within 6-8 hours upon transfer in a diffusion chamber to a wastewater treatment plant.

A striking result was that all the bacterial strains studied, belonging to three different genera contain a membrane-associated IDA-DH. This underlines the important role of this enzyme in the biodegradation of NTA. The involvement of IDA-DH in the biodegradation of other anthropogenic compounds is also possible, e.g. IDA was reported to be an in- 
termediate in the biodegradation of EDTA (Belly et al. 1975). Furthermore, recently an enzyme able to oxidize the herbicide glyphosate $\left(\mathrm{HOOC}-\mathrm{CH}_{2}-\right.$ $\mathrm{NH}-\mathrm{CH}_{2}-\mathrm{PO}_{3} \mathrm{H}_{2}$ ), which had a higher affinity for IDA than for glyphosate, was cloned from a glyphosate-utilizing Pseudomonas strain (R.E. Dick pers. comm.). IDA-DH from $C b$. heintzii ATCC 29600 had no affinity for glyphosate, because this compound was neither a substrate nor an inhibitor for our enzyme preparation (T. Uetz \& T. Egli unpubl.).

\section{Acknowledgements}

The authors are indebted to T. Bickle, G. Hamer, M. Page and E. Kellenberger for their encouragement and the many stimulating discussions. The linguistic help of C.A. Mason is gratefully acknowledged. We thank F. Bonhôte, St. Mattmüller and E. Grollimund for their help with chromatography and the opportunity to measure IDA in the laboratory of Sarasin AG in Basel. We thank T. Mini for the analysis of glycine and I. Thoenen for the preparation of antisera. Special thanks go to M. Bally and J. Kemmler for the help with some of the experiments and the analysis NTA. T.U. was supported by a grant from Lever AG Switzerland and Unilever Merseyside, UK. Additional financial support came from the Kanton Basel-Stadt.

\section{References}

Anonymous (1928) International critical tables. McGraw-Hill Book Company, New York

Auling G, Busse H-J, Egli T, El-Banna T \& Stackebrandt E (1993) Chelatobacter, gen. nov. and Chelatococcus, gen. nov., two novel genera of the alpha subclass of the Proteobacteria to accomodate the Gram-negative, obligately aerobic, nitrilotriacetate (NTA)-utilizing bacteria Chelatobacter heintzii, sp. nov., and Chelatococcus asaccharovorans, sp. nov.. System. Appl. Microbiol. (in press)

Bamforth CW \& Large PJ (1977) Solubilization, partial purification, and properties of $\mathrm{N}$-methylglutamate dehydrogenase from Pseudomonas aminovorans. Biochem. J. 161: 357-370

Bater AJ \& Venables WA (1977) The characterisation of inducible dehydrogenases specific for the oxidation of D-alanine, allohydroxyproline, choline and sarcosine as peripheral mem- brane proteins in Pseudomonas aeruginosa. Biochim. Biophys. Acta 468: 209-226

Belly RT, Lauff JJ \& Goodhue CT (1975) Degradation of ethylenediaminetetraacetic acid by microbial populations from an aerated lagoon. Appl. Microbiol. 29: 787-794

Boulton CA, Haywood GW \& Large PJ (1980) N-methylglutamate dehydrogenase, a flavoprotein purified from a new pink trimethylamine-utilizing bacterium. J. Gen. Microbiol. 117: 293-304

Cripps RE \& Noble AS (1973) The metabolism of nitrilotriacetate by a Pseudomonad. Biochem. J. 136: 1059-1068

Crofts AR, Meinhardt SW, Jones KR \& Snozzi M (1983) The role of the quinone pool in the cyclic electron transfer chain of Rhodopseudomons sphaeroides. Biochim. Biophys. Acta 723: 202-218

Crofts AR \& Wraight CA (1983) The electrochemical domain of photosynthesis. Biochim. Biophys. Acta 726: 149-185

Egli T, Bally M \& Uetz T (1990) Microbial degradation of chelating agents used in detergents with special reference to nitrilotriacetic acid (NTA). Biodegradation 1: 121-132

Egli T, Weilenmann H-U, El-Banna T \& Auling G (1988) Gramnegative, aerobic, nitrilotriactate-utilizing bacteria from wastewater and soil. Syst. Appl. Microbiol. 10: 297-305

Epstein SS (1972) Toxicological and environmental implications on the use of nitrilotriacetic acid as a detergent builder. Int. J. Environ. Stud. 2: 291-311

Firestone MK \& Tiedje JM (1978) Pathway of degradation of nitrilotriacetate by a Pseudomonas species. Appl. Environ. Microbiol. 35: 955-961

Focht DD \& Joseph HA (1971) Bacterial degradation of nitrilotriacetic acid. Can. J. Microbiol. 17: 1553-1556

Harlow E \& Lane D (1988) Antibodies. A Laboratory Manual. Cold Spring Harbour Laboratory, New York

Ingledew WJ \& Poole RK (1984) The respiratory chains of $E s-$ cherichia coli. Microbiol. Rev. 48: 222-271

Jenal-Wanner U (1991) Anaerobic degradation of nitrilotriacetate in a denitrifying bacterium: Purification and characterization of the nitrilotriacetate dehydrogenase/nitrate reductase enzyme complex. Doctoral thesis, ETH No. 9531, Swiss Federal Institute of Technology, Zürich, Switzerland

Kaki K, Yamaguchi H, Iguchi Y, Teshima M, Shirakashi T \& Kuriyama $M$ (1986) Isolation and characteristics of nitrilotriacetate degrading-bacteria. J. Ferment. Technol. 64: 103-108

Kasprzak AA, Papas EJ \& Steenkamp DJ (1983) Identity of the subunits and the stoichiometry of prosthetic groups in trimethylamine dehydrogenase and dimethylamine dehydrogenase. Biochem. J. 211: 535-541

Keesey J (1987) Biochemica Information. Boehringer Mannheim Biochemicals, Indianapolis

Kemmler J (1992) Biochemistry of nitrilotriacetate degradation in the facultatively denitrifying bacterium TE11. Doctoral thesis, No. 9983, Swiss Federal Institute of Technology, Zürich, Switzerland

Kita K, Vibat CRT, Meinhardt S, Guest JR \& Gennis RB (1989) One-step purification from Escherichia coli of complex II 
(Succinate:ubiquinone oxidoreductase) associated with succinate-reducible cytochrome $b_{5 s 6}$. J. Biol. Chem. 264: 2672-2677

Knecht R \& Young JY (1986) Liquid chromatographic determination of amino acids after gas-phase hydrolysis and derivatization with (dimethylamino)-azobenzenesulfonyl chloride. Anal. Chem. 58: 2375-2379

Laemmli UK (1970) Cleavage of structural proteins during the assembly of bacteriophage T4. Nature 227: 680-685

Matsushita K, Nonobe M, Shinagawa E, Adachi O \& Ameyama M (1987) Reconstitution of pyrroloquinoline quinone-dependant D-glucose oxidase respiratory chain of Escherichia coli with cytochrome $\varpi$ oxidase. J. Bacteriol. 169: 205-209

McFeters GA, Egli T, Wilberg E, Alder A, Schneider RP, Snozzi M \& Giger W (1990) Activity and adaptation of nitrilotriacetate (NTA)-degrading bacteria: field and laboratory studies. Water Res. 24: 875-881

Meiberg JBM \& Harder W (1979) Dimethylamine dehydrogenase from Hyphomicrobium X: purification and some properties of a new enzyme that oxidizes secundary amines. J. Gen. Microbiol. 115: 49-58

Olsiewski PJ, Kaczorowski GJ \& Walsh C (1980) Purification and properties of $\mathrm{D}$-amino acid dehydrogenase, an inducible membrane-bound iron-sulfur protein from Escherichia coli $B$. J. Biol. Chem. 255: 4487-4494

Pennoyer JD, Ohnishi T \& Trumpower BL (1988) Purification and properties of succinate-ubiquinone oxidoreductase complex from Paracoccus denitrificans. Biochim. Biophys. Acta 935: 195-207

Peterson GL (1979) A simplification of the protein assay method of Lowry et al. which is more generally applicable. Anal. Biochemistry $83: 346-356$

Pickaver AH (1976) The production of $\mathrm{N}$-nitrosoiminodiacetate from nitrilotriacetete and nitrate by microorganism growing in mixed culture. Soil Biol. Biochem. 8: 13-17

Reddy TLP \& Weber MM (1986) Solubilization, purification and characterization of succinate dehydrogenase from membranes of Mycobacterium phlei. J. Bacteriol. 167:1-6

Schneider R, Zürcher F, Egli T \& Hamer G (1989) Ion chroma- tography method for iminodiacetic acid determination in biological matrices in the presence of nitrilotriacetic acid. J. Chromat. 462: 293-301

- (1988) Determination of nitrilotriacetate in biological matrices using ion exclusion chromatography. Anal. Biochem. 173: 278-284

Tiedje JM (1980) Nitrilotriacetate: Hindsight and gunsight. In: Maki AM, Dickson KL \& Cairns J (Eds) Biotransformation and Fate of Chemicals in the Aquatic Environment (pp 114 119) ASM, Washington

Tiedje JM, Mason BB, Warren CB \& Malek EJ (1973) Metabolism of nitrilotriacetate by cells of Pseudomonas species. Appl. Microbiol. 25: 811-818

Towbin H, Staechelin T \& Gordon G (1979) Electrophoretic transfer of proteins from polyacrylamide gels to nitrocellulose sheets: procedure and applications. Proc. Natl. Acad. Sci. USA 76: $4350-4353$

Trijbels F \& Vogels GD (1966) Degradation of allantoin by Pseudomonas acidovorans. Biochim. Biophys. Acta 113: 292-301

Tushurashavili PR, Gavrikova EV, Lendenev AN \& Vinogradov AD (1985) Studies on the succinate dehydrogenating system. Isolation and properties of the mitochondrial succinate-ubiquinone reductase. Biochim. Biophys. Acta. 809: 145-159

Uetz T (1992) Biochemistry of nitrilotriacetate degradation in obligately aerobic, Gram-negative bacteria. Doctoral thesis, No. 9722, Swiss Federal Institute of Technology, Zürich, Switzerland

Uetz T, Schneider R, Snozzi M \& Egli T (1992) Purification and characterization of a two component monooxygenase that hydroxylates nitrilotriacetate (NTA) from Chelatobacter heintzii ATCC 29600. J. Bacteriol. 174: 1179-1188

Varadhachary A \& Maloney PC (1990) A rapid method for reconstitution of bacterial membrane proteins. Mol. Microbiol. 4: 1407-1411

Wanner U, Kemmler J, Weilenmann H-U, Egli T, El-Banna T \& Auling G (1990) Isolation and growth of a bacterium able to degrade nitrilotriacetate (NTA) under denitrifying conditions. Biodegradation 1: 31-41 